\title{
Compatibility of BeO Ceramics for MHD Generator Insulating Wall
}

\author{
By \\ Takayasu OKUO and Susumu NAGATA \\ (Electrotechnical Laboratory)
}

\section{Introduction}

For practical application of the MHD generating channel, it is urged that the material and the construction capable of withstanding the high-temperature and high-speed corrosive working fluid should be developed. As the insulating wall for this generating channel, a hot wall capable of maintaining electrical insulation under the temperature as high as that of the working fluid is advantageous from the view point of the thermal efficiency. Since, however, it is very difficult to accomplish these walls under the present state of material technology, semihot walls for use under reduced temperature conditions were proposed, and research and development of these walls have been pushed forward. However, it was pointed out that even with the semi-hot walls, it was difficult to be free from thermal shock failure due to sudden rises of heat input or stops of heat input in an emergency, or thermal stress failure in the steady running, and many problems existed to serve the long life even in the running under conditions of reduced thermal shocks.

For this reason, metal peg walls ${ }^{1)}$ developed by AVCO were re-evaluated as a type of cold walls, and after being modified partially, they seemed apparently to have been established as insulating walls for long duration MHD generators. However, as to this type of peg walls, some disadvantages may be pointed out:

(1) Construction is complicated and liable to cause leakage of water. (2) It is expensive for prepare the metal peg elements having complicated water channels. (3) Electrical insulation is deteriorated with the lapse of running time. (4). The wall surface in the vicinity of the electrode is damaged by electric current. (5) Cooling base plate holding the peg element can not withstand the super-high pressure cooling water used in generators of the commercialscale.

To solve these problems, the authors investigated physical properties of various ceramic materials, and selected $\mathrm{BeO}$ ceramics. The compatibility test was carried out on them by use of an MHD material test rig capable of a heat input of $1.2 \mathrm{MW}$ over
200 hours. Successfull development of cold type BeO ceramic insulating walls was realized.

\section{Materials for insulating wall}

As insulating heat-resisting materials adaptable to MHD conditions, $\mathrm{HfO}_{2}, \mathrm{ThO}_{2}, \mathrm{AIN}, \mathrm{BN}, \mathrm{BaO}$, $\mathrm{CaO}, \mathrm{ZrO}_{2}, \mathrm{MgO}, \mathrm{ThO}_{2}, \mathrm{ZrSiO}_{4}, \mathrm{Al}_{2} \mathrm{O}_{3}, \mathrm{SrZrO}_{3}$, spinel, $\mathrm{SrZr}, \mathrm{BaZr}, \mathrm{CaZr}$, ThZr, UrZr, etc. have so far been experimented ${ }^{2}$. Of these materials, $\mathrm{MgO}$, $\mathrm{CaZrO}_{3}, \mathrm{SrZrO}_{3}, \mathrm{ZrO}_{2}, \mathrm{Al}_{2} \mathrm{O}_{3}, \mathrm{BN}$ and $\mathrm{HfO}_{2}$ were judged as usable in the experiment machines, and $\mathrm{MgO}, \mathrm{Al}_{2} \mathrm{O}_{3}$ and $\mathrm{SrZrO}_{3}$ were proposed as promising for semi-hot walls. However, these oxides show a strong tendency toward thermal shock failure. Further with the exception of $\mathrm{Al}_{2} \mathrm{O}_{3}{ }^{3}$, they are hardly metallized, and hence it can be pointed out that there will be a difficulty in constructing insulating walls of these materials and in designing cooling structures which can be set to any desired surface temperature. In contrast, $\mathrm{BeO}$ ceramics show very high resistance to thermal shock damage and can be applied with established techniques for industrial metallizing which insures highly reliable ceramicto-metal bonding, indicating that a variety of possibilities can be found in controlling the wall temperature by making use of the large thermal conductivity. Indeed, these conditions are very advantageous for realizing insulating walls for MHD generators, but the beryllium poisoning ${ }^{\left.4 \sim^{26}\right)}$ and the water vapor reaction $^{27)}$ prevented $\mathrm{BeO}$ ceramics from practical application as the materials for MHD generators.

3. Experimental equipment and conditions Fig. 1 shows the schematic diagram of a test rig

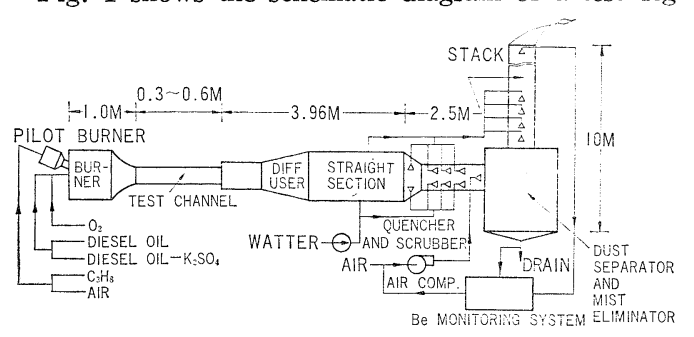

Fig. 1. Schematic diagram of the $1.2 \mathrm{MW}$ material test rig. 
Table 1. Burning conditions of the $1.2 \mathrm{MW}$ material test rig, and conditions of combustion gas plasma in the power generating channel.

\begin{tabular}{|c|c|c|c|c|c|c|c|c|}
\hline \multicolumn{6}{|c|}{ Burning condition } & & & \\
\hline \multicolumn{3}{|c|}{ Pilot burner } & \multicolumn{3}{|c|}{ Main burner } & \multicolumn{3}{|c|}{ Gas condition in the channel } \\
\hline $\mathrm{C}_{3} \mathrm{H}_{8}(\mathrm{~g} / \mathrm{s})$ & $\operatorname{Air}(\mathrm{g} / \mathrm{s})$ & Fuel $(\mathrm{g} / \mathrm{s})$ & $\mathrm{K}_{2} \overparen{\mathrm{SO}_{4}(\mathrm{~g} / \mathrm{s})}$ & $\mathrm{O}_{2}(\mathrm{~g} / \mathrm{s})$ & $\operatorname{Air}(g / s)$ & Mass flux (g/s. $\left.\mathrm{cni}^{2}\right)$ & Temp. $\left({ }^{\circ} \mathrm{C}\right)$ & Pressur (ata) \\
\hline 0.5 & 5.0 & 28 & 2.6 & 95 & 23 & 9.6 & 2530 & 1.1 \\
\hline
\end{tabular}

Table 2. Specifications for various $\mathrm{BeO}$ ceramics.

\begin{tabular}{|c|c|c|c|c|c|}
\hline Ceramics & Purity (\%) & Porosity (\%) & Production process & Source & Note \\
\hline A & 99 & 0 & cold press & NGK* & Commercial grade (* Nihon Gaishi Co.) \\
\hline $\mathrm{B}$ & $95 \sim 96$. & 0 & cold press & NGK KC** & Commercial grade (**Kyoto Ceramics Co.) \\
\hline $\mathrm{C}$ & $95 \sim 96$ & 0 & hot press & $\mathrm{KC}$ & Trially prepared \\
\hline $\mathrm{D}$ & 94 & $2 \sim 5$ & cold press & NGK & $\mathrm{BeO}-\mathrm{SiC}$ mixture \\
\hline $\mathrm{E}$ & $95 \sim 96$ & 0 & hot press & $\mathrm{KC}$ & $\mathrm{BeO}-\mathrm{Al}_{2} \mathrm{O}_{8}$ lamination \\
\hline $\mathrm{F}$ & $95 \sim 96$ & 0 & cold press & GIRIŃ́ $* * *$ & $\begin{array}{l}\mathrm{BeO}-\mathrm{Al}_{2} \mathrm{O}_{3} \mathrm{MgO} \text { lamination } \\
\text { (***Government Industrial Research Insti- } \\
\text { tute, Nagoya) }\end{array}$ \\
\hline
\end{tabular}

capable of a total heat input of 1.2 MW. The rated burning conditions and the conditions of combustion gas plasmas in the channel are summarized in Table 1 .

\section{Preparation of $\mathrm{BeO}$ ceramics and construction of insulating walls}

Table 2 shows specifications for six kinds of $\mathrm{BeO}$ ceramics for insulating walls. $\mathrm{BeO}$ ceramics $\mathrm{A}$ and $\mathrm{B}$ are leading products placed on the market for use as substrates of electronic devices. They are produced by cold press followed by a sintering treatment, and have purities of 95 to $99 \%$ and porosities of 0 to $5 \%$. These ceramic elements produced by the cold press process are shaped to specified dimensions by grinding (NGK) or metal die pressing (KC). BeO ceramics $\mathrm{C}$ are trially prepared specifically for MHD generator insulating walls by vacuum hot pressing. They received a very high degree of sintering and have a small light transmissibility. $\mathrm{BeO}$ ceramics $\mathrm{D}$ are prepared by mixing $\mathrm{BeO}$ with several $\%$ of fine powder of $\mathrm{SiC}$, followed by rubber pressing and sintering. They are developed as thermal shock resisting materials with a grayish white color. $\mathrm{BeO}$ ceramics $\mathrm{E}$ and $\mathrm{F}$ are laminated ceramics developed with emphasis on strengthened corrosion resistances by placing a thin $\mathrm{Al}_{2} \mathrm{O}_{3}$ or Spinel layer on the surface of the $\mathrm{BeO}$ body. $\mathrm{E}$ is prepared by vacuum hot pressing and shows a high bonding strength when the $\mathrm{Al}_{2} \mathrm{O}_{3}$ layer is about $0.5 \mathrm{~mm}$ thick. $\mathrm{F}$ is prepared by glazing a mixed layer of spinel and $\mathrm{MgO}$ of about $0.2 \mathrm{~mm}$ thickness on an element of the ceramic (B) in a vacuum furnace. The difference in the coefficient of thermal expansion between the $\mathrm{BeO}$ ceramics base and the glazing layer can be reduced by adjusting the mixing proportion between spinel and $\mathrm{MgO}$. These elements are shaped to specified dimensions, then metallized by Telefunken method on one surface, and $\mathrm{Ni}$ plated and brazed directly to a cooling substrate made of copper. To the ceramics $D$ to which this method of metallizing can not be applied, Ni plating by the non-electrolysis process is directly applied.

$\mathrm{BeO}$ ceramics for constructing insulating walls are shaped to the basic dimensions of a square having $24.5 \mathrm{~mm}$ sides or a hexagon having $30 \mathrm{~mm}$ diagonal lines. One or four or six elements are used to construct each unit wall for material testing. Structures of these walls are shown in Fig. 2 (a), (b) and (c). (a) shows a simple cooling structure in which the resistance to the water passage is so small that the pressure of the cooling water may not be high. With this structure, however, during the ceramic-to-metal brazing, insulating walls having an increased unit wall span deform in excess of assembling tolerances. After cooling, a severe cracking.
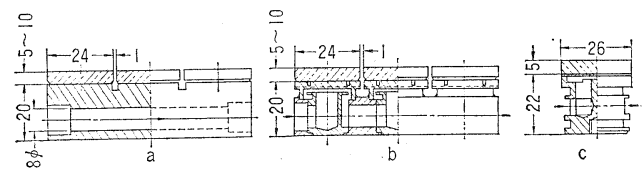

(a) : for low heat fluxes

(b) and (c) : for high heat fluxes

Fig. 2. Configurations of cold type insulating walls constructed of $\mathrm{BeO}$ ceramic elements.

occurs normal to the bonded surface due to internal stresses and stresses and strains caused by the different thermal expansion coefficients of both. Cooling structures in (b) and (c) are improved ones free from the above-mentioned troubles. They consist of separated cooling substrates so that the internal stress developed by brazing or heat load application may be relieved through easy occurrence of strains. Each of the independent cooling substrates is applied with the cooling water passage structure having high heat transfer. After this improvement, the insulating. 
walls as a whole deform only negligibly even if the unit wall span is increased by increasing the number of ceramic elements. If (a) is called "low heat flux type", (b) and (c) may be called "high heat flux type" insulating wall structure.

\section{Beryllium monitoring method}

In running the generating channel with $\mathrm{BeO}$ insulating walls, it is necessary to monitor beryllium concentrations in the exhaust gas over the whole period of operation as a means of safety control and also for gathering information on the damage of insulating walls. Monitoring of labor environments in producing facilities for beryllium products is accomplished by calorimetric analysis ${ }^{12)}$, fluorescent analysis ${ }^{28)}$, photometric analysis ${ }^{29), 30)}$, atomic absorption analysis ${ }^{31)}$, gas choromatgraphy ${ }^{32)}$, etc. In the present experimental equipment, the exhaust gas and cooling water in the gas quencher are sampled continuously and the quantitative analysis ${ }^{33}$ of beryllium is done by the calorimetric method so that the beryllium concentration in the exhaust gas may be measured precisely and a system for issuing an plant trip order in an emergency may be built. For the sampling ${ }^{34)}$ of the exhaust gas, a hydrophobic Milper filter $(35 \mu \times 25 \mathrm{~mm} \phi)$ and six impingers containing $75 \mathrm{cc}$ of $0.1 \mathrm{~N}$ hydochloric acid solution are connected in series to the suction side of an air compressor. The exhaust gas is passed through them at a rate of $30 \mathrm{l} / \mathrm{min}$ so that beryllium compounds in gas and solid phases may be collected. The sampling period is 1 hour. The sample taken is immediately inputted to the analytical instrument, and the results of analysis are sent to the operator of the test rig. If an unexpected trouble occurs in this monitoring process, there will be a time lag corresponding to the analytical time until a plant trip is effected. In this respect, as a tentative measure before the safe structure and safe operating conditions of $\mathrm{BeO}$ ceramic insulating walls are empirically determined, a channel provided with an observation hole is used so that the object under test may be visually observed at the same time as the monitoring process mentioned above.

\section{Compatibility of BeO insulating walls with MHD conditions}

\subsection{Outline of experiments on $\mathrm{BeO}$ ceranic}

\section{cold walls}

Heat fluxes from combustion plasmas to insulating walls increase with decreasing wall temperatures. However, cold wall ceramic elements are not so liable to fail due to thermal stresses as semi-hot walls. In the cold wall temperature region where the seed compound is in solid phase, however, significant problems are presented in constructing long life insulating walls, such as insulation deter- ioration due to accumulation of seed compounds and noncombustible products or electrical corrosion of insulating walls in the vicinity of electrodes. In this section, experiments conducted to clarify the basic characteristics under MHD conditions of cold type insulating walls fabricated of $\mathrm{BeO}$ ceramics will be outlined, and results of experiments and considerations will be given in 6.2. BeO semi-hot walls also will be described in this section.

\subsubsection{Thermal shock test When the heat} input is in a transient state, that is, it is increasing or decreasing, corresponding thermal stress changes occur in the ceramic element which constructs the insulating wall. If this transient state ends in a very short time, it is called "thermal shock". The thermal stress due to the severe change in temperature during the thermal shock often causes the fracture of brittle materials. If an insulating wall ceramic element is subjected to a thermal shock, cracking or spalling of the ceramic element may result, or the element may be disjoined from the portion where it has been bonded to the metal. When the ceramic element is fractured by a thermal shock while the heat input increases, the local damage will induce avalanche damage downstream of the combustion plasma. For this reason, the thermal shock resistance of the ceramic elements for constructing insulating walls is the necessary condition for determining the compatibility with MHD conditions. The thermal shock resistance is determined by the shape and the volume of the ceramic element if the material and thermal shock conditions are kept unchanged.

Insulating walls for thermal shock tests have unit walls each constructed of four elements $10 \mathrm{~mm}$ thick of materials A, B and C listed in Table 3 . This thickness is considered to be sufficient to keep the surface temperature in the cold wall temperature region against heat fluxes below $500 \mathrm{~W} / \mathrm{cm}^{2}$ and to withstand potential of several thousand volts relative to the casing (ground) which holds the insulating walls.

In the thermal shock test of series 1 , two sets of unit walls fabricated of the ceramic material $\mathrm{A}$ are mounted on a part of the duct wall of the water-cooled stainless steel channel. For comparison with the thermal shock resistance of this type of $\mathrm{BeO}$ ceramics, elements of $\mathrm{Al}_{2} \mathrm{O}_{3}$ ceramic $(17 \times 17 \times 5 \mathrm{t} \mathrm{mm}$, purity $96 \%$, porosity $0 \%$ ) was set in a part of the stainless steel downstream of the $\mathrm{BeO}$ unit walls so that they also be exposed to the combustion plasma.

In this test, the heat input to the combustor is varied in three steps, each of which comprises several heat cycles. At the end of each step, the specimen surface is examined for absence of damage before proceeding to the next step of heat cycles. The heat input given in the experiment is in an approximately rectangular wave form consisting of 
Table 3. Outline of compatibility tests for $\mathrm{BeO}$ cold insulating walls.

\begin{tabular}{|c|c|c|c|c|c|c|}
\hline $\begin{array}{c}\text { Experimental } \\
\text { items }\end{array}$ & $\begin{array}{l}\text { Heat flux } \\
\left(\mathrm{W} / \mathrm{cm}^{2}\right)\end{array}$ & $\begin{array}{l}\text { Duration } \\
\text { (hours) }\end{array}$ & $\begin{array}{c}\text { Thermal cycle } \\
\text { (times) }\end{array}$ & $\begin{array}{l}\text { Specimen No. } \\
\text { (cf. table 2) }\end{array}$ & $\begin{array}{l}\text { Applied current } \\
\left(\mathrm{A}-\mathrm{A} / \mathrm{cm}^{2}\right)\end{array}$ & $\begin{array}{l}\text { Experimental } \\
\text { results }\end{array}$ \\
\hline Thermal shock & 160 & $4 \mathrm{hr} ., 50 \mathrm{~min}$ & 10 & A & 0 & A, B : excellent \\
\hline tests & 160 & 8 & 9 & $A B D$ & 0 & $\mathrm{D}:$ poor \\
\hline \multirow{4}{*}{$\begin{array}{l}\text { Chemical } \\
\text { corrosion tests }\end{array}$} & 80 & 40 & 7 & $A B$ & 0 & \multirow{4}{*}{ A, B : excellent } \\
\hline & 80 & 50 & 2 & A B & 0 & \\
\hline & 80 & 4 & 1 & $\mathrm{~B}$ & $2-0.5$ & \\
\hline & 80 & 8 & 1 & $\mathrm{~B}$ & $2-1.0$ & \\
\hline \multirow{4}{*}{$\begin{array}{l}\text { Electrical } \\
\text { corrosion tests }\end{array}$} & 80 & 8 & 1 & $\mathrm{~B} \mathrm{C}$ & $4-1.0$ & \multirow{4}{*}{$\begin{array}{l}\text { B : excellent } \\
\text { C, F : good } \\
\text { E : poor }\end{array}$} \\
\hline & $140 \sim 200$ & 6 & 1 & $\mathrm{~B} C \mathrm{EF}$ & $10-1.0$ & \\
\hline & $140 \sim 200$ & $30 \mathrm{hr} ., 45 \mathrm{~min}$ & 1 & $\mathrm{~B} C \mathrm{E} F$ & $3-0.3$ & \\
\hline & $140 \sim 200$ & 115 & 14 & $\mathrm{~B} C \mathrm{E} \mathrm{F}$ & $24-2.4$ & \\
\hline
\end{tabular}

rising and falling times of 3 minutes at the maximum and steady state of 30 minutes on average. The first step comprises two heat cycles of $7.55 \mathrm{~g} / \mathrm{s}-\mathrm{cm}^{2}$ mass flux each, the second step comprises two cycles of $10.15 \mathrm{~g} / \mathrm{s}-\mathrm{cm}^{2}$ each. The integrated exposure time is 5.5 hours in total of eleven cycles. In the thermal shock test of series 2, each seven unit walls of ceramic materials $\mathrm{A}, \mathrm{B}$ and $\mathrm{C}$ were given nine rectangular wave heat cycles of $10.15 \mathrm{~g} / \mathrm{s}-\mathrm{cm}^{2}$ mass flux. The running time per cycle is 50 minutes, and the integrated exposure time is 8 hours in total.

6.1.2 Corrosion resistance test After confirmation of the compatibility of $\mathrm{BeO}$ ceramics with MHD conditions in the thermal shock test, the corrosion resistance was tested by long duration exposure to the combustion gas plasma, which contained seed compound, $\mathrm{K}_{2} \mathrm{SO}_{4}$, as given in Table 1. Unit walls constructed with two ceramic elements of $10 \mathrm{~mm}$ each of $\mathrm{A}$ and $\mathrm{B}$ were tested repeatedly for 42 hours (in 7 cycles) under the condtions of maximum heat flux of $95 \mathrm{~W} / \mathrm{cm}^{2}$ and maximum wall temperature of $280^{\circ} \mathrm{C}$, and after subsequent continuous running for 50 hours, corrosion damage to the ceramic element surface was not observed.

On the other hand, for selecting the material to fill up gaps between elements of $\mathrm{BeO}$ ceramic insulating walls, six kinds of commercially available castables of $\mathrm{Al}_{2} \mathrm{O}_{3}, \mathrm{MgO}$ and $\mathrm{BN}$ system were tested simultaneously with the above-mentioned corrosion test of ceramic elements to measure corrosion losses for gaps of 0.1 to $1.5 \mathrm{~mm}$.

\subsubsection{Electrical corrosion resistance test}

In the generating channel constructed of $\mathrm{Al}_{2} \mathrm{O}_{3}$ ceramic insulating walls, severe damage is observed in the vicinity of electrodes after a power generation experiment or an experiment with voltage applied from an external power source. Conceivable causes are: (1) arc spots transferring from the electrode to the insulating wall move along the conductive seed layer on the wall surface causing local thermal shocks which may result in spalling; (2) corrosive ions are gathered in an electrical field toward the electrode to cause damage there; (3) a conductive seed compound layer is deposited on the wall, and leakage current developed in this layer causes damage, etc. The purpose of the test described in this section is to examine $\mathrm{BeO}$ ceramics experimentally whether the electrical corrosion is a fracture common to the ceramic insulating walls.

In the electrical corrosion test of $\mathrm{BeO}$ ceramic insulating walls, DC voltage was applied continuously between electrodes in the Faraday and Hall directions from power sources, and the heat input and the current density were raised stepwise. After making sure that no damage was caused in the first step, proceeding to the second step was done. Conditions given in the first step are: heat input to the combustor $0.8 \mathrm{MW}$, mass flux $4.8 \mathrm{~g} / \mathrm{s}-\mathrm{cm}^{2}$, insulating wall heat flux $80 \mathrm{~W} / \mathrm{cm}^{2}$, wall temperature $150^{\circ} \mathrm{C}$. Under these conditions, a current of $4 \mathrm{~A}$ was applied for 4 hours in the Faraday direction through the water-cooled electrode of $4 \mathrm{~cm}^{2}$, then under the same current density, a current of double value, that is, $8 \mathrm{~A}$, was applied for 8 hours. Conditions given in the second step are: heat input to the combustor 1.2 MW, mass flux $9.6 \mathrm{~g} / \mathrm{s}-\mathrm{cm}^{2}$, insulating wall maximum heat flux $180 \mathrm{~W} / \mathrm{cm}^{2}$, wall temperature $250^{\circ} \mathrm{C}$. Under these conditions, water-cooled metallic electrodes of $11.5 \mathrm{~cm}^{2}$ were used. In this test, long-time density ( 30 hours $-0.3 \mathrm{~A} / \mathrm{cm}^{2}$ ), short-time ordinarylow-current current density. ( 6 hours $-1 \mathrm{~A} / \mathrm{cm}^{2}$ ) and short-time heat cycle high-current denstity ( 8 hours14 cycles-2 $\mathrm{A} / \mathrm{cm}^{3}$ ) experiments were conducted in succession.

6.1.4 BeO semi-hot wall It is expected that if a $\mathrm{BeO}$ ceramic element of $10 \mathrm{~mm}$ in thickness is used under the heat flux condition over $600 \mathrm{~W} / \mathrm{cm}^{2}$, the wall temperature reaches a value at which the seed compound condenses in liquid phase on the wall surface or higher.

Here, the insulating wall used under this wall temperature condition will be called "semi-hot wall". For $\mathrm{BeO}$ semi-hot walls, this wall temperature region is simulated by making ceramic element of $20 \mathrm{~mm}$ in thickness with respect to the heat flux of 100 to $150 \mathrm{~W} / \mathrm{cm}^{2}$ and formation of a thermal resistance layer at the portion where this element is bonded to the cooling metal. The unit insulating 


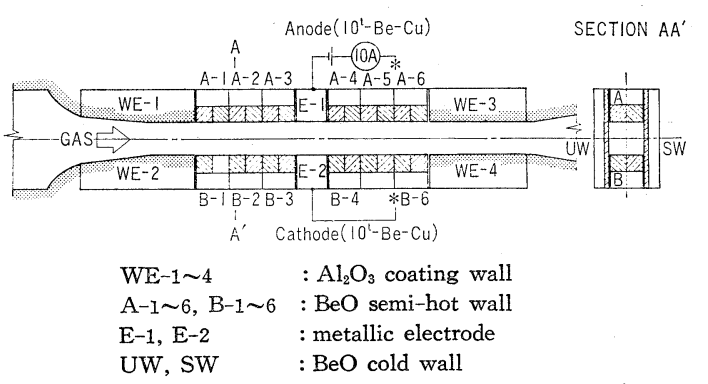

Fig. 3. Arrangement of unit walls and electrodes in the $\mathrm{BeO}$ semi-hot wall experiment.

wall was constructed of four $\mathrm{BeO}$ ceramic elements (of B in Table 2) of which surface area was $14.4 \mathrm{~cm}^{2}$.

Fig. 3 shows the arrangement of unit walls and $\mathrm{Cu}-\mathrm{Be}$ alloy electrodes in the channel. The side wall is constructed of a $\mathrm{BeO}$ cold wall. In the experiment with semi-hot walls, the mass flow of the combustion gas plasma is raised stepwise. In each step, Be in the exhaust gas and the cooling water drain from the gas quencher is analysed to check for electrical corrosion by a current application of 10 amperes (at about $1 \mathrm{~A} / \mathrm{cm}^{2}$ ).

\subsection{Experimental results and considera- tions}

6.2.1 Evaluation of the compatibility Experimental conditions and results for each experimental item on various $\mathrm{BeO}$ ceramics are outlined in Table 3. In the insulating walls constructed of ceramic element $\mathrm{A}$ and $\mathrm{B}$ in Table 2 , no significant difference was noticed in the compatibility with MHD conditions, but lower purity ceramics $B$ having better metallizing ability showed higher reliability in bonding to the metal. In ceramics $\mathrm{B}$ and $\mathrm{C}$ manufactured by $\mathrm{KC}$, a compact texture owing to a high degree of sintering suppresses the diffusion of metallizing metal into the ceramic, and therefore, separation of the metallized layer out of the brazed portion occurred at a probability of about $20 \%$. These ceramics of compact texture showed cracking normal to the bonded surface in the thermal shock test. In contrast, ceramics B manufactured by NGK of a slightly lower degree of sintering showed excellent thermal shock resistance. Ceramics D have the lowest bonding strength of the brazed portion among the specimens tested, and caused separation of the bonded portion at a rate as high as over $50 \%$. The ceramic $\mathrm{D}$ has the texture with $\mathrm{SiC}$ fine powder distributed in $\mathrm{BeO}$ matrix. By several runs of thermal shock test, growth of crystal grains in the surface layer contacting with the combustion gas plasma and many fine cracks originating from $\mathrm{SiC}$ grains were observed. SiC grains exposed to the plasma are not seen after test, and the surface appears just like the craters. By X-ray analysis, potassium compounds were detected in the depression and peripheral areas.

After the corrosion test of $\mathrm{BeO}$ cold walls by long time combustion plasma exposure, no change was observed microscopically on the element surface. No ingress of potassium into the ceramic was noticed upon analysis with an X-ray microanalyzer.

Table 4 shows six kinds of fillers used in $\mathrm{BeO}$ insulating walls of $10 \mathrm{~mm}$ in thickness, their binders, clearance between ceramic elements, corrosion depth and area ratio, and the condition of the filler after experiment. Among them, $\mathrm{Al}_{2} \mathrm{O}_{3}$ using Monofix-A as binder is the best one, and $\mathrm{MgO}$ using aqua solution of $\mathrm{MgSO}_{4}$ as binder follows it. $\mathrm{Al}_{2} \mathrm{O}_{3}$ using silicon and its fixing agent as binder is suitable for filling up the gaps between the insulating wall and the electrode or casing because of relatively easy filling and disjointing operation, but its corrosion in the surface portion contacting with the combustion gas plasma is relatively severe.

The electrical breakdown proceeding from the combustion gas plasma through the ceramic to the casing occurs mainly in the fill-up portion, and therefore the withstand voltage of this portion of the ceramic insulating wall is very important for the construction of the generating channel. Especially, when the clearance between ceramic elements is wide, insulation deterioration to be caused by corrosion of the fill-up portion or ingress of potassium will lead to degrading of the function of the insulating wall itself. Thus, by reducing the clearance between ceramic elements, the influence of the filler can be reduced. If it is assumed that the brazing temperature of the $\mathrm{BeO}$ ceramic element onto the cooling substrate is $820^{\circ} \mathrm{C}$ and the thermal expansion of $\mathrm{BeO}$ at this temperature is $0.60 \%$, the feasible minimum clearance for $25 \mathrm{~mm}$ square ceramic

Table 4. Outline of experimental conditions and results on fillers for $\mathrm{BeO}$ cold type insulating walls.

\begin{tabular}{|c|c|c|c|c|c|c|}
\hline \multirow{2}{*}{ No. } & \multirow{2}{*}{ Matrix } & \multirow{2}{*}{ Binder } & \multirow{2}{*}{ Clearance $(\mathrm{mm})$} & \multicolumn{2}{|c|}{ Erosion } & \multirow{2}{*}{ Note } \\
\hline & & & & depth (mm) & ratio $(\%)$ & \\
\hline 1 & $\mathrm{Al}_{2} \mathrm{O}_{3}(\mathrm{AM}-21)$ & Shinetu silicon & $0.5 \sim 1.2$ & 1 & 100 & brittleness \\
\hline 2 & $\mathrm{Al}_{2} \mathrm{O}_{3}(\mathrm{AM}-21)$ & Monofix-A & 1.2 & $0.5 \sim 1$ & 5 & solidity \\
\hline 3 & $\mathrm{Al}_{2} \mathrm{O}_{2}(\mathrm{Al}-\mathrm{S})$ & $\mathrm{CaO}$ & $0.5 \sim 1.0$ & $0.5 \sim 1.5$ & 50 & \\
\hline 4 & $\mathrm{Al}_{2} \mathrm{O}_{3}(\mathrm{Al}-\mathrm{S})$ & $\mathrm{CaO}+$ Monofix $-\mathrm{A}$ & $0.5 \sim 1.0$ & $0.2 \sim 0.3$ & 100 & brittleness \\
\hline 5 & $\mathrm{MgO}$ (Fomag-98) & $\mathrm{MgSO}_{4}$ & 1.4 & $0.1 \pm 0.1$ & 100 & solidity \\
\hline 6 & $\mathrm{BN}$ & Coloidal silica & 1.2 & 1 & 100 & \\
\hline
\end{tabular}


elements is $0.15 \mathrm{~mm}$. If these narrow fill-up widths are obtainable, the corrosion may be negligibly small even if silicon- $\mathrm{Al}_{2} \mathrm{O}_{3}$ fillers are used.

Since good results were obtained in long-time low-current density and short-time ordinary-current density voltage application experiments on ceramics $\mathrm{B}$ and $\mathrm{C}$, short-time high-current density heat cycle experiments on ceramics $\mathrm{B}$ and $\mathrm{C}$, short-time highcurrent density heat cycle experiments on ceramics $\mathrm{B}, \mathrm{C}, \mathrm{E}$ and $\mathrm{F}$ were con- ducted. The results of the experiments indicate that after application of a current of 24 amperes (at $2.1 \mathrm{~A} / \mathrm{cm}^{2}$ ) for 50 hours in total in ten heat cycles, the surface of the insulating wall constructed of ceramic elements B manufactured by NGK is quite complete. In the case of ceramics $\mathrm{E}$ prepared by lamination of $\mathrm{Al}_{2} \mathrm{O}_{3}$ on $\mathrm{BeO}$ by hot pressing, $\mathrm{Al}_{2} \mathrm{O}_{3}$ in the run of current surface layer portion was partially separated by one application test, and as the test is repeated, the separation extended over the entire surface. Ceramics $\mathrm{F}$ having lamination of an $\mathrm{MgO}$ mixture on the $\mathrm{BeO}$ ceramic withstood over several runs of thermal shock and current application test.

Fig. 4 shows the results obtained in experiments on $\mathrm{BeO}$ semi-hot walls. Changes in indications of $\mathrm{P}-\mathrm{Pr}$ and $\mathrm{C}-\mathrm{A}$ thermocouples inserted in the ceramic elements, surface temperatures extrapolated

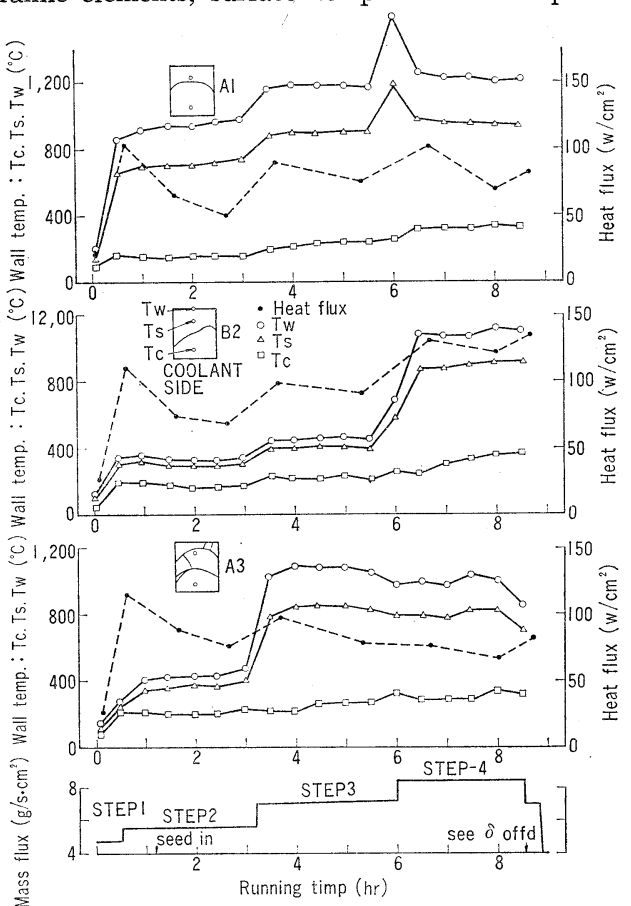

Fig. 4. Relationship between the temperature"at measuring points, heat fluxes, and mass fluxes of the combustion gas plasma through the ceramic element of the $\mathrm{BeO}$ semi-hot insulating wall, showing that the cracks occur as the mass flux changes. therefrom, and in heat fluxes in unit insulating walls are shown corresponding to mass flux changes of the combustion gas plasma. In the same figure, the relationship between the condition of cracking in elements, points of time at which these cracks occur, and mass flux changes are shown, too. The $\mathrm{BeO}$ ceramic element in the unit wall cracks at the middle portion with the heat input change from step 1 to step 2 for A1, B1, B4, A5, B5 and B6, from step 2 to step 3 for $A 3$, and from step 3 to step 4 for A2, B2 and A4. This cracking raises the surface temperature. In this way, cracks occur in all unit walls except A6. Secondary damage due to abrasion is seen in the remaining portions of unit walls of $\mathrm{A} 1 \sim \mathrm{A} 3$ and $\mathrm{B} 1 \sim \mathrm{B} 3$ from which the layer over cracks was broken away during operation. $\mathrm{BN}$ used as the filter in this experiment, bound with colloidal silica, was entirely corroded, and for this reason, similar abrasion occurred at the corners of same elements which were free from breakage. Upper portions of the ceramic elements which were free from spalling during operation separated conchoidally at a slight shock during disassembly after operation. Coloring, which is probably due to the copper alloy electrode, was seen on semi-hot walls (of B4 B6) downstream of the anode, but no apparent damage due to current application was noticed.

6.2.2 Heat loss Fig. 5 shows heat losses in the direction of flow of the combustion gas plasma through the test rig with the heat inputtaken as a parameter. Under the influence of the cooled boundary layer in the upstream portion, the distribution of heat flux through the insulating walls in the channel has the maximum value at 150 to $200 \mathrm{~mm}$ from the tapered end of nozzle.

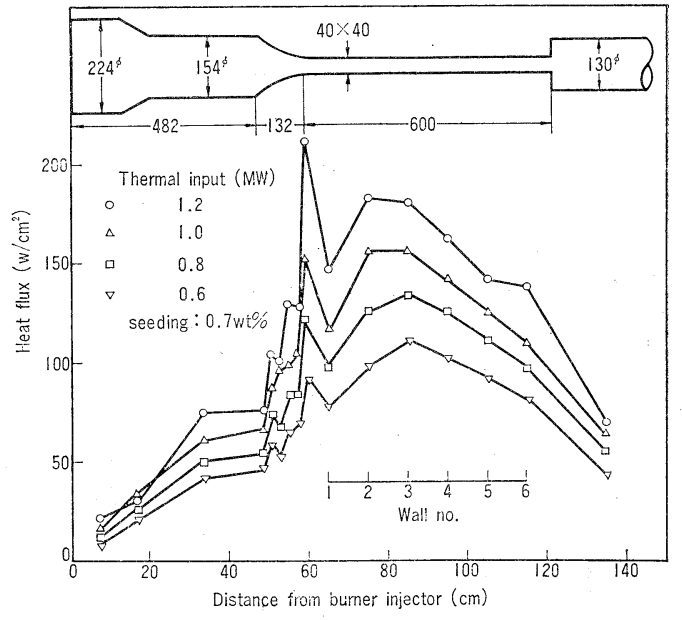

Fig. 5. Heat loss distribution along the direction of gas flow in the $1.2 \mathrm{MW}$ material test rig (for the channel constructed of $\mathrm{BeO}$ cold insulating walls). 
Under the rated burning conditions, the maximum heat flux through the insulating walls is limited to $180 \mathrm{~W} / \mathrm{cm}^{2}$ for the present test rig insofar as the specimen is exposed to the flow of the combustion gas plasma. Since, however, in the case of the commercial plant, the factor of heat loss due to radiation will be added, the maximum heat flux over $200 \mathrm{~W} / \mathrm{cm}^{2}$ is expected. For simulating the heat flux in this case, the authors trially constructed a stagnation type abrasion test channel, with which the heat flux test up to $450 \mathrm{~W} / \mathrm{cm}^{2}$ was possible on specimens of $50 \times 50 \mathrm{~mm}$, as will be reported in detail in another paper.

In Fig. 6 the heat loss of the $\mathrm{BeO}$ cold wall is expressed in a non-dimensionalized form, where Nusselt number is plotted against the local Reynolds number. The deta agrees well with the following

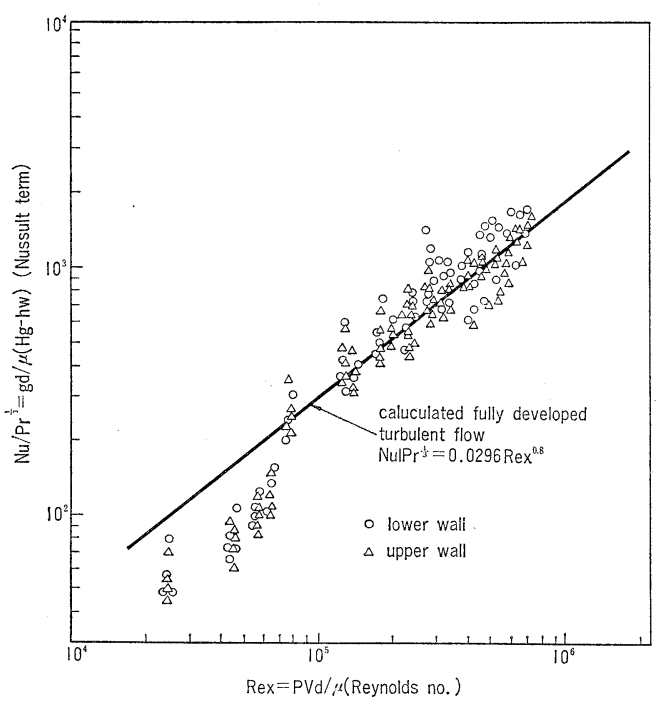

Fig. 6. Measurement of heat transfer of $\mathrm{BeO}$ ceramic cold insulating walls.

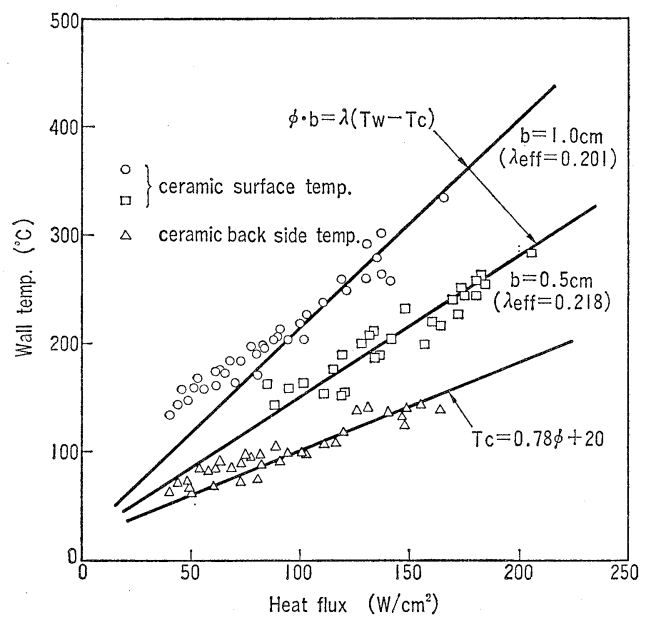

Fig. 7. Wall temperature vs. heat fluxes for the $\mathrm{BeO}$ cold insulating walls. formula for the heat transfer by forced convection of turbulent flows which have developed sufficiently on a flat plate in the region of Reynolds numbers over $10^{5}$.

$$
N_{u} / P_{r^{1 / 3}}=0.296 R_{e x}{ }^{0.8}
$$

Fig. 7 shows the surface and back side temperatures of $\mathrm{BeO}$ cold wall ceramic elements measured with thermocouples and plotted against the heat flux measured by calorimetry. This graph indicates that the relationship between the surface temperature and the heat flux of $\mathrm{BeO}$ cold walls constructed of ceramic elements of thickness $b$ agrees well with the value calculated on the assumption of the thermal conductivity of $\mathrm{BeO}$ ceramic elements having the theoretical density of $80 \%$. That is, let the wall surface temperature be $T w\left({ }^{\circ} \mathrm{C}\right)$, the thermal conductivity of the ceramic element be $\lambda\left(\mathrm{cal} / \mathrm{s}-\mathrm{cm}^{2}-^{\circ} \mathrm{C}\right)$, and the heat flux be $\phi\left(\mathrm{W} / \mathrm{cm}^{2}\right)$, then the following experimental formula can be derived.

$$
T w=\left(b / \lambda_{\text {eff }} J+0.78\right) \phi+20 \cdots \cdots \cdots \cdots(2)
$$

The effective average thermal conductivity $\lambda_{e f f}$ in Eq. (2) is 0.201 for $b=10 \mathrm{~mm}$ and 0.218 for $b=$ $5 \mathrm{~mm}$. These values lie on the thermal conductivity temperature dependency curves given by Touloukian ${ }^{35}$ ) with the theoretical density of $\mathrm{BeO}$ taken as a parameter where the theoretical density is 80 to $85 \%$.

6.2.3 Beryllium monitoring For the measurement of $\mathrm{Be}$ concentrations in the exhaust gas, it is desirable for high precision analysis to introduce a large amount of sampling gas in a short time into the measuring system and collect it quickly. However, because of limited collecting liquid and filter capabilities, it took an introducing time of over 1 hour with our experimental equipment if the analytical sensitivity and the measuring precision determined from the allowable concentration of beryllium are to be realized simultaneously. The beryllium concentration in the exhaust gas during operation was determined from analysis of the collecting liquid and filter, while $10 \mathrm{~m}^{3}$ of the atmospheric air was analysed as background. The background concentration was below $3 \mathrm{ppb}$ which is the analytical limit of beryllium. The background of beryllium in the cooling water drain from the gas quencher was determined through combustion employing a dummy channel of water-cooled stainless steel. The analytical value of beryllium in this case was at the same level as the background of the atmospheric air.

Fig. 8 shows changes in beryllium and potassium concentrations in the stack gas and gas quencher cooling water drain during a 30 hour durability test in which the rated heat input input was given to cold type $\mathrm{BeO}$ insulating walls. In this experiment, beryllium of $17 \mathrm{ppb}$ and $12 \mathrm{ppb}$ was detected in the cooling water drain 6 hours and 14 hours after starting, respectively. These values correspond to 


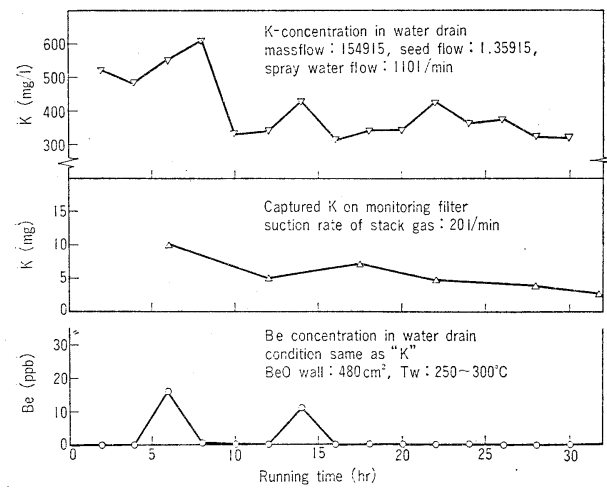

Fig. 8. Results of beryllium and potassium monitoring of the $\mathrm{BeO}$ cold insulating wall.

$1.6 \times 10^{-3} \mathrm{mg}$ and $1.13 \times 10^{-3} \mathrm{mg}$ in terms of weight losses. A total of $33.6 \mathrm{~m}^{3}$ of stack gas was introduced into the monitoring system for 30 hour continuous runing, but beryllium was not detected from the filter after experiment within the analytical sensitivity $\left(2 \times 10^{-4} \mathrm{mg}\right)$, nor from the collecting liquid in excess of the background. The analytical limit of this filter is $0.006 \mu \mathrm{g} / \mathrm{m}^{3}$ of the beryllium concentration. The results of the beryllium monitoring were the same as those from other experiments on cold type $\mathrm{BeO}$ insulating walls. It is considered that the beryllium compound separated from the insulating wall is carried by the combustion gas, and partly accumulates, together with the seed compound, on the inside wall of the exhaust duct located downstream of the channel, the rest is absorbed by the cooling water in the gas quencher and discharged in the drain, or is discharged to the atmosphere together with the stack gas. On assumption of this way of dispersion and that the beryllium compound is in the form of $\mathrm{Be}(\mathrm{OH})_{2}$ and behaves similarly to the potassium compound, the dispersion ratio of beryllium can be estimated by throwing a known amount of potassium into the combustor, and measuring the ratio of yields of potassium discharged into the atmosphere, drained out into the waste water tank and accumulating on the inside wall of the exhaust equipment from the analytical values. The yield in each part was calculated for a unit amount of potassium thrown into the combustor: $0.39 \times 10^{-4}$ in the stack gas discharged into the atmosphere and $0.47 \times 10^{-4}$ in the drain. The remainder is to accumulate on the inside wall of the apparatus. The large amount of seed compound accumulating on the inside wall of the exhaust duct has distributed in a crystalline form over the bottom of the inside wall of the straight section starting downstream of the diffuser. The accumulation was mostly $\mathrm{K}_{2} \mathrm{SO}_{4}$ but no beryllium was detected by luminescent analysis. However, if the assumption that the yielding ratio of potassium is applicable to beryllium is justifiable, the amount of beryllium in the stack gas, which corresponds to the maximum beryllium concentration of $17 \mathrm{ppb}$ detected in the cooling water drain, is $2.23 \times 10^{-4} \mu \mathrm{g}$ or $5.8 \times 10^{-7} \gamma$.

Fig. 9 shows the results of beryllium monitoring in the experiment with $\mathrm{BeO}$ semi-hot walls. Large broken pieces spalled off the ceramic element surface are collected, together with solid combustion products, by the dust separator and settled in the waste water. Therefore, the total loss of the insulating wall converted from the beryllium concentration given in this graph is smaller than the net loss obtained as the difference in weight prior to and after experiment.; At the mass flow of $114 \mathrm{~g} / \mathrm{s}$ (in step 3 ), the beryllium concentration is somewhat high.

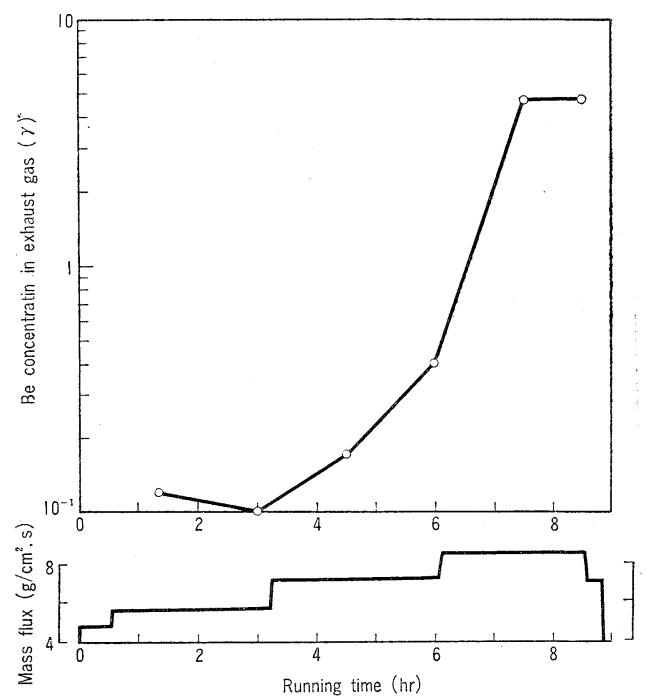

Fig. 9. Be concentration of the exhaust gas in the $\mathrm{BeO}$ semi-hot insulating wall experiment.

It increases substantially with the rise of the wall temperature irrespective of the presence or absence of current application. The maximum beryllium concentration in the experiment is $4.66 r$ at the outlet of the stack, this value being about $20 \%$ of the maximum allowable concentration for short-time running.

\subsubsection{Problems in ceramic-to-metal bon-} ding When a ceramic and a metal having largely different coefficients of thermal expansion are brazed to each other, deformations or internal stresses occur in the process of cooling from the working temperature. If the metal has a larger coefficient of thermal expansion than the ceramic, and both are free to deform, they bend with the centor of curvature placed on the metal side. The side of the metal bonded to the ceramic is subjected to compressive stresses and the opposite side to tensile stresses. As the result, if a metal which is liable to creep is selected for 
the cooling substrate, it is possible to somewhat alleviate internal stresses and deformations. If the coeffcient of thermal expansion of the ceramic is close to that of the metal or a low temperature brazing material is used, the difference in coefficients of thermal expansion between both can be invalidated. As the cooling substrate, the authors used high purity copper having a large coefficient of thermal expansion in order to improve the cooling effect and uniformalize the temperature distribution on the bonded surfaces. Therefore, if the bonding method used is not to permit deformations, it is necessary to sandwich a metal such as molybdenum or tungsten between the copper and the ceramic or simultaneously braze an alloy such as covar having a suitable thickness on the back side of the copper. Such a multi-layered structure makes the brazing operation complicated and develops relatively large residual stresses. On the other hand, the use of the low temperature brazing material simplifies the brazing operation, but produces much pores which results in a thick bonded layer and a bonding strength significantly lower than in the case of high temperature brazing materials. To examine the bonding strength, the water quenching test at $200^{\circ} \mathrm{C}$ was made ten times with the results teat one of 32 test specimens was separated after completion of all test runs. Tnen by the thermal shock test on the test rig, about $5 \%$ of ceramic elements were separated by being subjected to mechanical shocks after stopping of running under the condition of the heat flux of $160 \mathrm{~W} / \mathrm{cm}^{2}$ for 5 cycles. The X-ray photograph of the condition of bonding with the low temperature bonding material indicates that the bonded layer has an irregular pore distribution and the ratio of actually bonded to expected area is 60 to $80 \%$. In this way, low temperature brazing materials turned out to give poorly reproducible bonding, that is, the bonding strength is degraded by thermal stress fatigue.

Then, stress relieving structures were investigated for direct ceramic-metal bonding with the use of high temperature brazing materials. Bonding of a ceramic element to copper results in cracking normal to the surface of the ceramic element if the thickness of copper is in excess of four times that of the ceramic element. It was found that when the thickness of copper was below $3 \mathrm{~mm}$ for the ceramic element of 5 to $10 \mathrm{~mm}$, the internal stress was reduced by plastic deformation and creep of copper so that cracking was eliminated. This finding was applied for high heat flux type insulating wall structures.

\section{Conclusion}

1) For constructing insulating walls, two types of commercial and four types of trially prepared $\mathrm{BeO}$ ceramic elements were tested under the MHD conditions with the finding that a $95 \%$ purity commercial ceramic manufactured by cold pressing and sintering followed by glazing with a mixture of $\mathrm{MgO}-\mathrm{Al}_{2} \mathrm{O}_{3}$ (spinel) showed excellent performance.

2) By experimental examination of structures of insulating walls constructed of $\mathrm{BeO}$ ceramic elements, high heat flux type and low heat flux type of insulating walls with cooled structures have been developed with excellent insulating characteristics.

3) $\mathrm{BeO}$ cold type insulating walls constructed of $10 \mathrm{~mm}$ thick ceramic elements showed high compatibility with the MHD conditions at the wall temperature below $350^{\circ} \mathrm{C}$ and the heat flux below $180 \mathrm{~W}$ $/ \mathrm{cm}^{2}$. On the other hand, semi-hot type insulating walls constructed of about $20 \mathrm{~mm}$ thick $\mathrm{BeO}$ ceramic elements were damaged in most cases by spalling at the wall temperature of 1,000 to $1,200^{\circ} \mathrm{C}$ and the heat flux of 70 to $140 \mathrm{~W} / \mathrm{cm}^{2}$.

4) For the relationship among the wall temperature, heat flux, ceramic element thickness and thermal conductivity of $\mathrm{BeO}$ cold walls, the following experimental formula has been obtained.

$$
T w=\left(b / \lambda_{\text {eff }} J+0.78\right) \phi+20
$$

The effective thermal conductivity $\lambda_{e f f}$ of 5 and $10 \mathrm{~mm}$ thick $\mathrm{BeO}$ elements is 0.201 and 0.218 , respectiely, which correspond to the Touloukian's value at the theoretical density of 80 to $85 \%$.

5) The heat loss of $\mathrm{BeO}$ cold walls in a nondimensional form agrees well with the formula for the heat loss of turbulent flows on a flat plate in the range of Reynolds numbers over $7 \times 10^{4}$.

6) The maximum concentration of $\mathrm{Be}$ emitted into the atmospheric air during experiment of the $\mathrm{BeO}$ cold walls is $6.0 \times 10^{-3} \gamma$ (as obtained by monitoring) or $5.8 \times 10^{-7} \gamma$ (as calculated from the $\mathrm{BeO}$ loss and the yield of $\mathrm{K}$ ), both being much lower than the allowable limit. BeO semi-hot walls showed Be emissions of 4.66 corresponding to $20 \%$ of the allowable limit of Be concentrations in the atmos. pheric air.

\section{Acknowledgements}

The opportunity for this study was given by Dr. Kozo Fushimi, ex-manager of the Energy Division of the Electrotechnical Laboratory, who gave the authors valuable advice and encouragement as well.

For processing of the experimental data, the authors obtained assistance of Mrs. Setsuko Saito. In addition, the authors obtained much assistance and valuable advice from members of the Energy Conversion Section in the performance of this study, and authors wish to thank all these cooperations.

\section{References}

1) Novack, M. E., et al., ASME, No. 63-WA-348.

2) Wolff, "Special Ceramics" (1972).

3) Morikawa et al., Smp. Int. MHD, 5, 3-g(II) (1968).

4) Cholak, J., et al., Toxicity of Beryllium, No. ASD-TR-62-7-665 
5) Hardy, H. L., Nerw England J. of Med .,25 (1965).

6) Lieben, J., Air Eng., Nov. (1961).

7) Romney, E. M., et al., Science 135, 16 (1961).

8) R. Robinson, Arch. Environ. Health, 17, Aug. (1968).

9) J.R. Prine., Am. J. Clin. Pathol. 45, 4 (1966).

10) Hall, R.H., et al., A.M.A. Arch. Ind. Hyg. Occupational Med. 2, 25 (1950).

11) Sterner. J. H., et al., A.M.A. Arch. Ind. Hyg. Occupational Med., 4, 123 (1951).

12) H.H. Weber,et al. Zentr. Gewerbehyg. Unifallverhut. 10, 41 (1933).

13) S. Marradi-Fabroni, Med. Lavoro. 26, 298 (1935).

14) F. Hyslop, et al., Natl. Inst. Health Bull., 181 (1943).

15) H.E. Stokinger. et al., A.M.A. Arch. Ind. Hyg. Occupational Med. 1, 379 (1950).

16) R.H. Hall, et al., A.M.A. Arch. Ind. Hyg. Occupational Med. 2, 25 (1950).

17) Prine, J. R., et al., Am. J. Clin. Pathol. 45, 4 (1966).

18) Vorwald, A. J., Progress Report, U.S. Public Health Service Grant, C-2507 (C4) SEOH (1959)

19) J.M. DeNardi, et al., Am. J. Med. 7, 345-55(1949).

20) P.H. Henneman, et al., J. Clin. Inv. 35, 1229-42 (1956).
窯業協会誌 $83[7] 1975331$

21) E.H. Stokinger,et al., Arch. Ind. Hyg. 8, 493-506 (1953).

22) A.A. Fisher, Arch. Dermat. \& Syph. 68, 214-16 (1953).

23) Schubert. J., et al., Arch. Ind. Health 19, 169 (1959).

24) S. Shima, Jap. J. Hyg. 17, 22 (1962).

25) S. Shima, et al., Jap. J. Hyg. 19, 101 (1964).

26) S. Shima, Jap. J. Hyg. 25, 1 (1970).

27) W.I. Stuart, et al., J. Nuc. Mat. 14, 417-24 (1964).

28) Donaldson, H. M., et al., Ind. Hyg. J., Aug. 28085 (1961).

29) Sill, C. W., et al., Anal. Chem. 31, 598 (1959).

30) Sill, C. W., et al., Anal. Chem. 33, 1671 (1961).

31) Kennan, R. G., et al., Amer. Ind. Hyg. Assoc. J. 25, 254 (1965).

32) Thompson, R. J., et al., Inst. Soc. of Am. Symp., May, 9-17 (1969)

33) S. Sibata, et al., Jap. Analyst, 18, 604-07 (1969).

34) Ross, W. D., et al., Talanta, 15, 87 (1968).

35) Y.S. Touloukian, "Thermophysical Proparties of High Temperature Solid Materials", Macmillan Company, (1967) p. 4

[Received September 28, 1974]

\section{MHD 発電機用絶縁壁に対する $\mathrm{BeO}$ 磁器の適合性}

\section{奥尾隆 保・永 田進 \\ （工業技術院電子技術総合研究所）}

オープンサイクル MHD 発電チャンネル用長寿命絶 縁壁を開発しこの特性を調べた.この絶縁壁は $\mathrm{BeO}$ 磁 器の素子を用いて構成し, これを熱入力 $1.2 \mathrm{MW}$ 材料 試験機によって, 而熱衝撃試験, 腐蝕試験及び通電耐久 試験を実施することによって, 絶縁壁構造と安全使用条
件を検討した。この結果， $180 \mathrm{~W} / \mathrm{cm}^{2}$ 以下の燃焼ガスプ ラズマによる熱負荷条件ではコールド壁方式として優れ た絶縁壁構成が可能であることを示した。

(9/28/1974 受付) 